\title{
Oxidative Modification of Neurofilament-L by Copper-catalyzed Reaction
}

\author{
Nam Hoon Kim and Jung Hoon Kang* \\ Department of Genetic Engineering, Chongju University, Chongju 360-764, Korea \\ Received 4 April 2003, Accepted 23 April 2003
}

\begin{abstract}
Neurofilament-L (NF-L) is a major element of neuronal cytoskeletons and known to be important for neuronal survival in vivo. Since oxidative stress might play a critical role in the pathogenesis of neurodegenerative diseases, we investigated the role of copper and peroxide in the modification of NF-L. When disassembled NF-L was incubated with copper ion and hydrogen peroxide, then the aggregation of protein was proportional to copper and hydrogen peroxide concentrations. Dityrosine crosslink formation was obtained in copper-mediated NF-L aggregates. The copper-mediated modification of NF-L was significantly inhibited by thiol antioxidants, Nacetylcysteine, glutathione, and thiourea. A thioflavin-T binding assay was performed to determine whether the copper/ $/ \mathrm{H}_{2} \mathrm{O}_{2}$ system-induced in vitro aggregation of $\mathrm{NF}-\mathrm{L}$ displays amyloid-like characteristics. The aggregate of NF$\mathrm{L}$ displayed thioflavin $\mathrm{T}$ reactivity, which was reminiscent of amyloid. This study suggests that copper-mediated NF$L$ modification might be closely related to oxidative reactions which may play a critical role in neurodegenerative diseases.
\end{abstract}

Keywords: Copper, Hydrogen peroxide, Modification, Neurofilament-L

\section{Introduction}

Neurofilaments give axons their structural integrity and define axonal diameter (Hoffman et al., 1987; Brady et al., 1993). Neurofilaments are composed of three subunits. These subunits are identified as light (NF-L), medium (NF-M), and heavy (NF-H), which assemble in a $6: 2: 1$ ratio to form long macromolecular filaments (Nixon et al., 1986; Nixon et al., 1992). Consequently, NF-L is more abundant than the other two subunits in neurons. NF-L is capable of homologous

*To whom correspondence should be addressed.

Tel: 82-43-229-8562; Fax: 82-43-229-8432

E-mail: jhkang@chongju.ac.kr assembly, whereas NF-M and NF-H are not component to assemble in the absence of NF-L (Cohlberg et al., 1995). Abnormal accumulation of neurofilaments in neurons is one of the pathological hallmarks of various neurodegenerative disorders. In patients with Parkinson's disease, Lewy bodies (LBs) are cytoplasmic inclusions that are consistently present and have the greatest frequency in neurons of the substatia nigra. Also, locus ceruleus NF proteins have been identified immunohistochemically as major protein components of the LB filament (Forno, 1986; Gidd et al., 1989). Peroxynitrite may nitrate tyrosine residues of NF-L, thereby altering NF assembly and causing neurofilament accumulation in neurons (Crow et al., 1997).

Reactive oxygen species (ROS) from metabolic or adventitious reduction of $\mathrm{O}_{2}$ are associated with the etiology of human diseases (Eum and Kang, 1999; Halliwell and Gutteridge, 1999). The oxidation of cellular proteins has been described under many pathological conditions (Ames et al., 1993; Berlett et al., 1997). Cellular metabolism generates oxygen species, such as hydrogen peroxide, hydroxyl radical, and superoxide anion. Transition metals, such as iron and copper, react with hydrogen peroxide to produce hydroxyl radical through Fenton-type reaction and can induce the oxidative modification of DNA, protein, and lipids (Halliwell and Gutteridge, 1999). During exposure to hydrogen peroxide, many proteins with metal binding sites will probably be susceptible to oxidative damage, and free metal ions could be released. The oxidative modification of $\mathrm{Cu}, \mathrm{Zn}-$ superoxide dismutase by hydrogen peroxide induced the release of copper ions (Kang and Kim, 1997). Free copper that is released from a certain $\mathrm{Cu}, \mathrm{Zn}$-SOD mutant in familial amyotrophic lateral sclerosis (Yim et al., 1996; Eum and Kang, 1999) and copper that is reduced by the amyloid precursor protein in Alzheimer's disease (Multhaup et al., 1996) were suggested to be a part of etiology for these diseases. Therefore, the reaction of copper with hydrogen peroxide may be associated with the abnormal modification of neurofilaments, which may be involved in the pathogenesis of neurodegenerative disorders.

In this study, we investigated whether the copper-catalyzed oxidation system is involved in the aggregation of NF-L. Our 
results revealed that the copper-catalyzed reaction induced the aggregation of NF-L and the formation of amyloid-like fibrils. These results suggest that the copper-catalyzed oxidation system may be involved in the oxidative stress-induced aggregation of NF-L in neurodegenerative diseases.

\section{Materials and Methods}

Expression and purification of neurofilament-L A full-length cDNA clone of mouse NF-L in a pET-3d vector, a generous gift from Dr. Beckman (University of Alabama), was transfected into E.coli (BL21). The protein expression was performed as previously described (Ozdener et al., 2002). Bacteria were grown in a Luria broth that was supplemented with $1 \mathrm{mM}$ isopropyl $\beta$-Dthiogalactopyranoside, beginning at an OD $600 \mathrm{~nm}$ reading of 0.8 . Incubation was at $37^{\circ} \mathrm{C}$ for $3 \mathrm{~h}$. Bacteria were harvested by centrifugation $\left(4,000 \times g\right.$ for $10 \mathrm{~min}$ at $\left.4^{\circ} \mathrm{C}\right)$ and resuspended in a standard buffer (50 mM Mes, $170 \mathrm{mM} \mathrm{NaCl}, 1 \mathrm{mM}$ DTT, pH 6.25). The cells were lysed with a French press at a pressure of 20,000 psi and centrifuged at $8,000 \times g$ for $15 \mathrm{~min}$ at $4^{\circ} \mathrm{C}$. The supernatant was incubated for $3 \mathrm{~h}$ at $37^{\circ} \mathrm{C}$, and then was centrifuged at $100,000 \times g$ for $20 \mathrm{~min}$ at $25^{\circ} \mathrm{C}$. The pellets that contained the aggregated NF-L proteins were washed twice with a standard buffer before they were dissolved in a urea buffer (25 mM Na-phosphate, $\mathrm{pH}$ 7.5, $6 \mathrm{M}$ urea, $1 \mathrm{mM}$ EGTA, and $1 \mathrm{mM}$ DTT). The sample was loaded onto a DEAE-Sepharose column. The column was washed with the urea buffer. The column was eluted with a linear $25-500 \mathrm{mM}$ phosphate gradient in the urea buffer and the NF-L was eluted between 300 and $360 \mathrm{mM}$ phosphate. These fractions were pooled and either used directly or stored at $-70^{\circ} \mathrm{C}$ for later experiments. The protein concentration was determined by the BCA method (Smith et al., 1985).

Oxidation of protein Oxidative modification of NF-L $(0.8 \mathrm{mg}$ / ml) was carried out by incubation of the protein with $\mathrm{CuSO}_{4}$ and $\mathrm{H}_{2} \mathrm{O}_{2}$ in $10 \mathrm{mM}$ potassium phosphate buffer $(\mathrm{pH} 7.5)$ at $37^{\circ} \mathrm{C}$. After the incubation, the mixtures were then placed into a Ultrafree-MC filter and centrifuged at 13,000 rpm for $1 \mathrm{~h}$, then washed with Chelex 100-treated water and centrifuged for $1 \mathrm{~h}$ at the same speed. This was repeated four times. The filtrate was dried by a freeze drier and dissolved with a phosphate buffer.

Analysis of modified protein After treatment with various concentrations of $\mathrm{Cu}^{2+}$ and $\mathrm{H}_{2} \mathrm{O}_{2}$ for various periods of time, the reaction mixture samples were diluted with a $5 x$ loading-sample buffer $(62.5 \mathrm{mM}$ Tris, $10 \%$ SDS, 20\% glycerol, 10\% 2mercaptoethanol, $0.01 \%$ bromophenol blue) and heated in boiling water for $10 \mathrm{~min}$ before loading onto SDS-PAGE (Treerattrakool $e t$ al., 2002). An aliquot of each sample was subjected to SDS-PAGE, as described by Laemmli (Laemmli, 1970), using a 12\% acrylamide slab gel. The gels were stained with $0.15 \%$ Coomassie Brilliant Blue R-250.

Detection of o,o-dityrosine The reactions for the detection of o,odityrosine were carried out with NF-L $(0.8 \mathrm{mg} / \mathrm{ml}), \mathrm{CuSO}_{4}$, and $\mathrm{H}_{2} \mathrm{O}_{2}$ in a total volume of $300 \mu \mathrm{l}$. The samples were diluted with $2.7 \mathrm{ml}$ of
Chelex 100-treated water and transferred to a cuvette $(3 \mathrm{ml})$. The fluorescence emission spectrum of the sample was then monitored in the 340-500 region (exitation, $325 \mathrm{~nm}$ ) using Spectrofluorometer SMF 25 (Bio-Tek Instruments, Winooski, USA).

Thioflavin-T binding assay Thioflavin-T staining was performed to determine whether the copper-catalyzed oxidation reactioninduced NF-L aggregates displayed amyloid-like characteristics. Briefly, NF-L reacted with $\mathrm{CuSO}_{4}$ and $\mathrm{H}_{2} \mathrm{O}_{2}$ in $10 \mathrm{mM}$ potassium phosphate (pH 7.4). The sample mixture $(15 \mu \mathrm{l})$ was added to $2 \mathrm{ml}$ of $10 \mu \mathrm{M}$ thioflavin- $\mathrm{T}$ in $50 \mathrm{mM}$ Glycine $/ \mathrm{NaOH}, \mathrm{pH} 8.5$, and analyzed with a fluorescence spectrometer. The sample fluorescence was monitored in the 460-520 region (exitation at $450 \mathrm{~nm}$ ) using Spectrofluorometer SMF 25 (Bio-Tek Instruments).

\section{Results}

An SDS-PAGE analysis showed that NF-L remained intact after incubation with $\mathrm{CuSO}_{4}$ or $\mathrm{H}_{2} \mathrm{O}_{2}$ alone (Fig. 1A). In contrast, the staining intensity for the original protein was reduced, and new high molecular weight material was visualized at the stacking/separating gel interface when NF-L was incubated with both $\mathrm{Cu}^{2+}$ and $\mathrm{H}_{2} \mathrm{O}_{2}$. These results suggest that both $\mathrm{Cu}^{2+}$ and $\mathrm{H}_{2} \mathrm{O}_{2}$ were required for the aggregation of NF-L. The aggregation of NF-L became apparent at $50 \mu \mathrm{M}$ $\mathrm{CuSO}_{4}$; the aggregation increased up to $500 \mu \mathrm{M} \mathrm{CuSO}_{4}(\mathrm{Fig}$. 1B). The aggregation of NF-L was also increased in a $\mathrm{H}_{2} \mathrm{O}_{2}$ concentration-dependent manner.

It has been reported that the o,o-dityrosine crosslink formation between the dityrosine residues may play a part in the formation of the oxidative covalent protein crosslink (Stadtman et al., 1993). We investigated the formation of o,odityrosine during the $\mathrm{Cu}^{2+} / \mathrm{H}_{2} \mathrm{O}_{2}$ system-mediated NF-L aggregation by measuring the fluorescence emission spectrum between 340 and $500 \mathrm{~nm}$ with an excitation at $325 \mathrm{~nm}$. The reactions were carried out with NF-L in the presence of 300 $\mu \mathrm{M} \mathrm{CuSO}_{4}$ for 0 and $7 \mathrm{~h}$ at $37^{\circ} \mathrm{C}$. As the reactions proceeded, the emission peak at $410 \mathrm{~nm}$ increased, due to the formation of o,o-dityrosine crosslinks (Fig. 2). Oxidative protein crosslinks are produced by several means, such as direct interactions between carbon-centered radical derivatives of amino acids. Our result suggested that the tyrosine-tyrosine crosslink formation might participate in the $\mathrm{Cu}^{2+} / \mathrm{H}_{2} \mathrm{O}_{2}$ systemmediated NF-L aggregation.

The effect of antioxidant molecules on the aggregation of NF-L by the $\mathrm{Cu}^{2+} / \mathrm{H}_{2} \mathrm{O}_{2}$ system was studied. The aggregation of NF-L by the $\mathrm{Cu}^{2+} / \mathrm{H}_{2} \mathrm{O}_{2}$ system was significantly suppressed in the presence of $\mathrm{N}$-acetylcysteine, glutathione, and thiourea (Fig. 3 ). These results suggest that hydroxyl radical might play a critical role in the aggregation of NF-L by the $\mathrm{Cu}^{2+} / \mathrm{H}_{2} \mathrm{O}_{2}$ system.

Neurofilament is a major component of aggregates that form amyloid-like fibrils in Lewy bodies (LBs) of Parkinson's disease (PD) and senile plaques of Alzheimer's disease (AD). A thioflavin- $T$ binding assay was performed to determine 

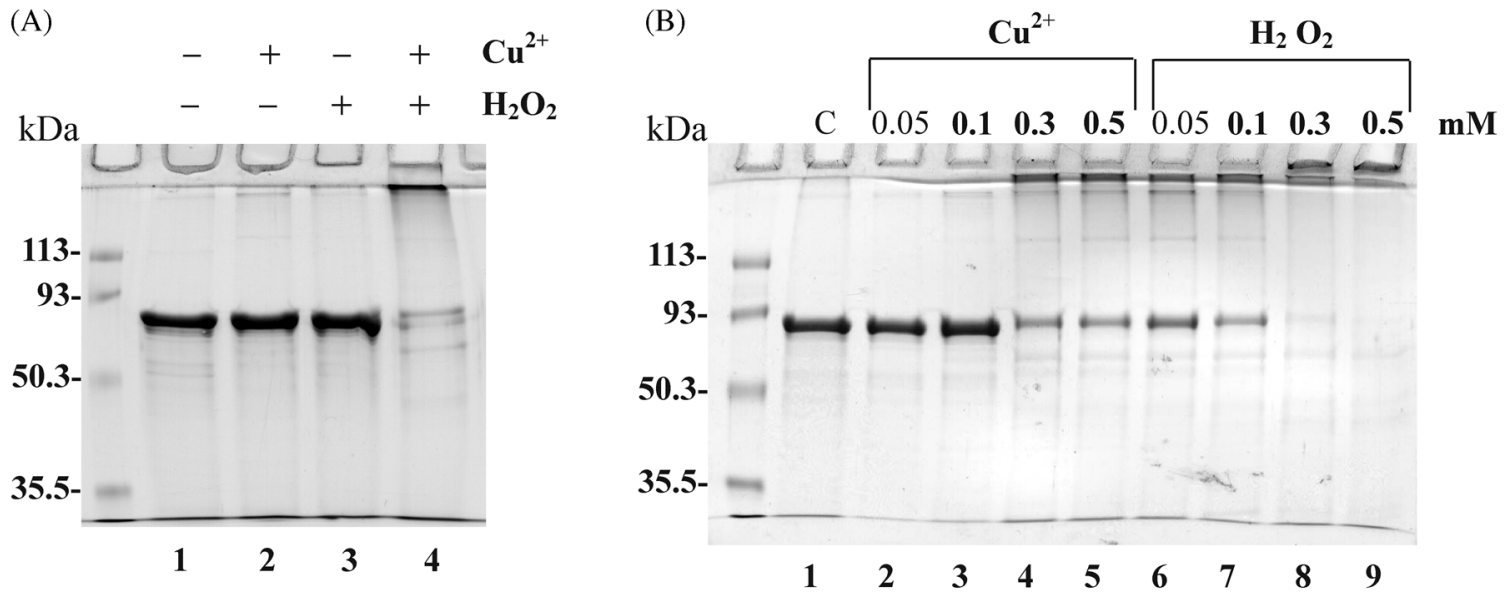

Fig. 1. Modification of NF-L by copper-mediated oxidation reaction. (A) NF-L $(0.25 \mathrm{mg} / \mathrm{ml})$ was incubated with $\mathrm{Cu}^{2+}$ and $\mathrm{H}_{2} \mathrm{O}_{2}$ in $10 \mathrm{mM}$ phosphate buffer $(\mathrm{pH} 7.4)$ at $37^{\circ} \mathrm{C}$ for $4 \mathrm{~h}$. Lane 1 , NF-L control; lane 2, NF-L $+0.3 \mathrm{mM} \mathrm{Cu}^{2+}$; lane $3, \mathrm{NF}-\mathrm{L}+0.1 \mathrm{mM} \mathrm{H} \mathrm{O}_{2}$; lane 4, NF-L + $0.3 \mathrm{mM} \mathrm{Cu}{ }^{2+}+0.1 \mathrm{mM} \mathrm{H}_{2} \mathrm{O}_{2}$. (B) NF-L $(0.8 \mathrm{mg} / \mathrm{ml})$ was incubated with various concentrations of $\mathrm{Cu}^{2+}$ and $\mathrm{H}_{2} \mathrm{O}_{2}$ in $10 \mathrm{mM}$ phosphate buffer $\left(\mathrm{pH} \mathrm{7.4)}\right.$ at $37^{\circ} \mathrm{C}$ for $4 \mathrm{~h}$. Lane 1, NF-L control; lane 2, $0.05 \mathrm{mM} \mathrm{Cu} u^{2+}+0.1 \mathrm{mM} \mathrm{H}_{2} \mathrm{O}_{2}$; lane $3,0.1 \mathrm{mM}$ $\mathrm{Cu}^{2+}+0.1 \mathrm{mM} \mathrm{H}_{2} \mathrm{O}_{2}$; lane 4, $0.3 \mathrm{mM} \mathrm{Cu}^{2+}+0.1 \mathrm{mM} \mathrm{H}_{2} \mathrm{O}_{2}$; lane 5, $0.5 \mathrm{mM} \mathrm{Cu}^{2+}+0.1 \mathrm{mM} \mathrm{H}_{2} \mathrm{O}_{2}$; lane 6, 0.3 $\mathrm{mM} \mathrm{Cu}^{2+}+0.05 \mathrm{mM} \mathrm{H}_{2} \mathrm{O}_{2}$; lane 7, $0.3 \mathrm{mM} \mathrm{Cu}^{2+}+0.1 \mathrm{mM} \mathrm{H}_{2} \mathrm{O}_{2}$; lane $8,0.3 \mathrm{mM} \mathrm{Cu}^{2+}+0.3 \mathrm{mM} \mathrm{H}_{2} \mathrm{O}_{2}$; lane $9,0.3 \mathrm{mM} \mathrm{Cu}^{2+}+0.5 \mathrm{mM} \mathrm{H}_{2} \mathrm{O}_{2}$. The molecular weight marker positions $(\mathrm{kDa})$ are indicated on the left.

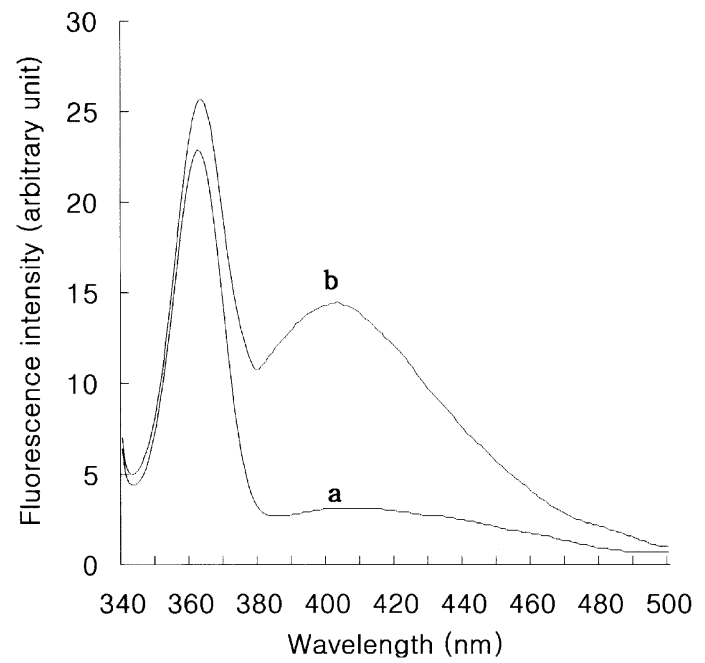

Fig. 2. Fluorescence spectra of copper-mediated NF-L modification. The fluorescence spectra of the formation of dityrosine were observed when NF-L $(0.8 \mathrm{mg} / \mathrm{ml})$ was incubated with $\mathrm{Cu}^{2+}$ and $\mathrm{H}_{2} \mathrm{O}_{2}$. (a) NF-L control, (b) NF-L with $0.3 \mathrm{mM}$ $\mathrm{Cu}^{2+}$ and $0.1 \mathrm{mM} \mathrm{H}_{2} \mathrm{O}_{2}$

whether the $\mathrm{Cu}^{2+} / \mathrm{H}_{2} \mathrm{O}_{2}$ system-induced in vitro aggregation of NF-L displayed amyloid-like characteristics. As shown in Figure 4, strong reactivity was obtained with NF-L, indicating that the $\mathrm{Cu}^{2+} / \mathrm{H}_{2} \mathrm{O}_{2}$ system may induce the formation of amyloid-like fibrils of NF-L.

\section{Discussion}

NF-L, a major structural protein that is important for the

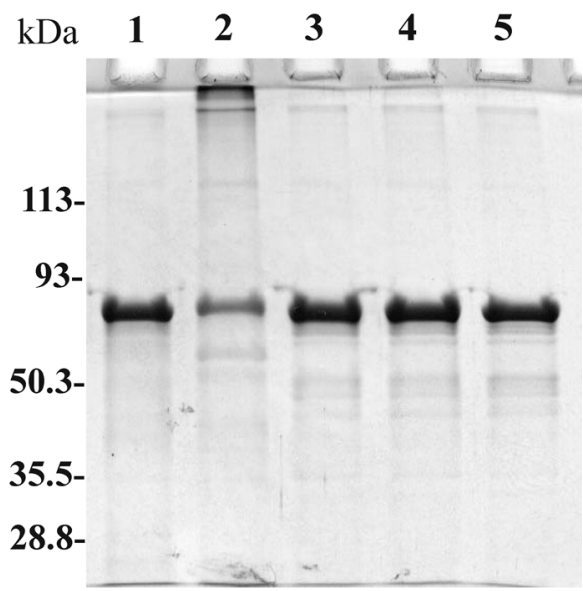

Fig. 3. Effect of thiol antioxidants on copper-mediated NF-L modification. NF-L $(0.8 \mathrm{mg} / \mathrm{ml})$ was incubated with $0.3 \mathrm{mM} \mathrm{Cu}{ }^{2+}$ and $0.1 \mathrm{mM} \mathrm{H}_{2} \mathrm{O}_{2}$ in $10 \mathrm{mM}$ phosphate buffer (pH 7.4) at $37^{\circ} \mathrm{C}$ for $4 \mathrm{~h}$ in the presence of thiol antioxidants. Lane 1, NF-L control; lanes 2 and 5, no addition; lane $3,20 \mathrm{mM} \mathrm{N}$ acetylcysteine; lane 4, $20 \mathrm{mM}$ glutathione; lane 5, $20 \mathrm{mM}$ thiourea. The molecular weight marker positions $(\mathrm{kDa})$ are indicated on the left.

survival of motor neurons, was modified by oxidative stress. Neurofilaments are susceptible to oxidation, in part because they are among the most abundant proteins in a cell. Previous studies suggested that oxidative stress might play a critical role in the pathogenesis of PD (Halliwell, 1989; Youdim et al., 1989; Jenner et al., 1996). Trace metals (such as copper and iron, which are present in the biological system) react with hydrogen peroxide and then produce the hydroxyl radicals. This reactive oxygen might lead to the cross-linking and 


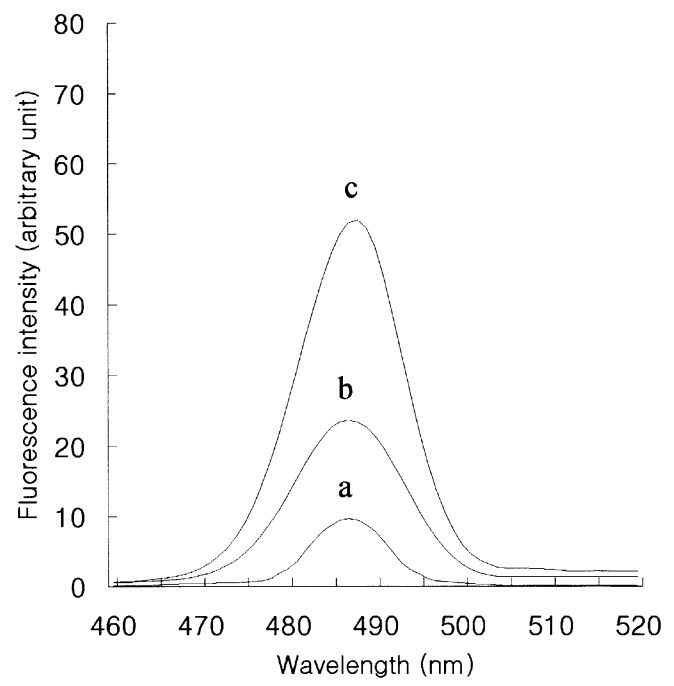

Fig. 4. Fluorescence spectra of thioflavin -T-bound NF-L aggregate. The fluorescence spectra of the product by the reaction of thioflavin-T with NF-L aggregate were observed when NF-L $(0.8 \mathrm{mg} / \mathrm{ml})$ was incubated with $\mathrm{Cu}^{2+}$ and $\mathrm{H}_{2} \mathrm{O}_{2}$. (a) $0.3 \mathrm{mM} \mathrm{Cu}^{2+}$ and $1 \mathrm{mM} \mathrm{H}_{2} \mathrm{O}_{2}$, (b) NF-L control, (c) NF-L with $0.3 \mathrm{mM} \mathrm{Cu}^{2+}$ and $1 \mathrm{mM} \mathrm{H}_{2} \mathrm{O}_{2}$.

aggregation of amyloidogenic molecules (Markesbery et al., 1999). The cleavage of the metalloproteins by oxidative damage may lead to increases in the levels of metal ions in some biological cells (O'Connell et al., 1987). The releasing of copper ions from $\mathrm{Cu}, \mathrm{Zn}$-SOD could be induced by a free radical-generating function of the enzyme (Kang and Kim, 1997). Since copper promotes NF-L self-aggregation, it is possible that the aberrant accumulation of copper ion might act as a risk factor for neurodegenerative diseases. It has been reported that the copper concentration significantly increased in the cerebrospinal-fluid of PD patients (Pall et al., 1987). Recently, it was reported that the cerebrospinal-fluid copper concentration increased 2.2-fold in AD patients (Multhaup et al., 1996). These results suggest that the iron or coppercatalyzed oxidative reaction might contribute to the pathogenesis of neurodegenerative diseases.

Many antioxidant molecules have been proposed for the therapeutic agents of neurodegenerative diseases (Edwards et al., 2002; Floyd et al., 2002; Nagano et al., 2003). Our results show that thiol antioxidants, such as $\mathrm{N}$-acetylcycteine, glutathione, and thiourea, could protect the aggregation of NF$\mathrm{L}$ by the copper-catalyzed oxidation system. One of the mechanisms by which antioxidants can protect their biological targets from oxidative stress is the chelation of transition metals, such as copper and iron, preventing them from participating in the deleterious Fenton reaction. Thiol antioxidants are very efficient copper chelating agents (Jimenez et al., 2000; Zhu et al., 2002). These compounds might be able to bind $\mathrm{Cu}^{2+}$ and prevent some $\mathrm{Cu}^{2+}$-dependent radical reactions. $\mathrm{N}$-Acetylcysteine is a scavenger of hydroxyl radicals, as determined by a pulse radiolysis experiment (Felix et al., 1996). Therefore, it can be assumed that thiol antioxidants may protect the aggregation of NF-L by the copper-catalyzed oxidation system through the combination of scavenging of $\cdot \mathrm{OH}$ radicals and the chelation of copper ion.

In conclusion, the present results suggest that the aggregation of NF-L was induced by the copper-catalyzed oxidation system that involved $\cdot \mathrm{OH}$ generation from $\mathrm{H}_{2} \mathrm{O}_{2}$. Therefore, the copper-catalyzed oxidation system-mediated NF-L aggregation might be involved in the pathogenesis of neurodegenerative diseases.

Acknowledgments We thank Dr. J. S. Beckman (University of Alabama) for providing cDNA of mouse neurofilament-L.

\section{References}

Ames, B. N., Shigenaga, M. K. and Hagen, T. M. (1993) Oxidants, antioxidants, and the degenerative diseases of aging. Proc. Natl. Acad. Sci. USA 90, 7915-7922.

Berlett, B. S. and Stadtman, E. R. (1992) Protein oxidation in aging, disease, and oxidative stress. J. Biol. Chem. 272, 2031320316.

Brady, S. T. (1993) Motor neurons and neurofilaments in sickness and in health. Cell 73, 1-3.

Cohlberg, J. A., Hajarian, H., Tran, T., Alipourjeddi, P. and Noveen, A. (1995) Neurofilament protein heterotetramers as assembly intermediates. J. Biol. Chem. 270, 9334-9339.

Crow, F., Ye, Y. Z., Strong, M., Kirk, M., Barnes, S. and Beckman, J. S. (1997) Superoxide dismutase catalyzes nitration of tyrosines by peroxynitrite in the rod and head domains of neurofilament-L. J. Neurochem. 69, 1945-1953.

Edwards, M. J., Hargreaves, I. P., Heales, S. J., Jones, S. J., Ramachandran, V., Bhatia, K. P. and Sisodiya, S. (2002) Nacetylcysteine and Unerricht-Lundborg disease: variable response and possible side effects. Neurology 59, 1447-1449.

Eum, W. S. and Kang, J. H. (1999) Release of copper ions from the familial amyotrophic lateral sclerosis-associated $\mathrm{Cu}, \mathrm{Zn}$ superoxide dismutase mutants. Mol. Cells 9, 110-114.

Felix, K., Pairet, M. and Zimmermann, R. (1996) The antioxidative activity of the mucoregulatory agents: ambroxol, bromhexine and N-acetyl-L-cysteine. A pulse radiolysis study. Life Sci. 59, 1141-1147.

Floyd, R. A. and Hensley, K. (2002) Oxidative stress in brain aging. Implications for therapeutics of neurodegenerative diseases. Neurobiol. Aging 23, 795-807.

Forno, L. S. (1986) The Lewy body in Parkinsons disease. Adv. Neurol. 45, 35-42.

Gibb, W. R. G. and Lees, A. J. (1989) The significance of the Lewy body in the diagnosis of idiopathic Parkinsons disease. Neuropathol. Appl. Neurobiol. 15, 27-44.

Halliwell, B. and Gutteridge, J. M. C. (1999) Free radicals in biology and medicine. Oxford Press, New York, USA.

Halliwell, B. (1989) Oxidants and the central nervous system: some fundamental questions. Is oxidant damage relevant to Parkinson's disease, Alzheimer's disease, traumatic injury or stroke? Acta Neurol. Scand. 126, 23-33.

Hoffman, P., Cleveland, D., Griffin, J., Landes, P., Cowan, N. and 
Price, D. (1987) Neurofilament gene expression: a major determinant of axonal caliber. Proc. Natl. Acad. Sci. USA 84, 3472-3476.

Jenner, P. and Olanow, C. W. (1996) Oxidative stress and the pathogenesis of Parkinson's disease. Neurology 47, S161-170.

Jimenez, I. and Speisky, H. (2000) Effects of copper ions on the free radical-scavenging properties of reduced glutathione: implications of a complex formation. J. Trace. Elem. Med. Biol. 14, 161-167.

Kang, J. H. and Kim, S. M. (1997) Fragmentation of human $\mathrm{Cu}, \mathrm{Zn}$-superoxide dismutase by peroxidative reaction. Mol. Cells 7, 553-558.

Laemmli, U. K. (1970) Cleavage of structural proteins during the assembly of the head of bacteriphage T4. Nature 227, 680-685.

Markesbery, W. R. and Carney, J. M. (1999) Oxidative alterations in Alzheimer's disease. Brain Pathol. 9, 133-146.

Multhaup, G., Schlicksupp, A., Hesse, L., Behler, D., Ruppert, T., Masters, C. L. and Beyreuther, K. (1996) The amyloid precursor protein of Alzheimer's disease in the reduction of copper(II) to copper(I). Science 271, 1406-1409.

Nagano, S., Fujii, Y., Yamamoto, T., Taniyama, M., Fukada, K., Yanagihara, T. and Sakoda, S. (2003) The efficacy of trientine or ascorbate alone compared to the combined treatment with these two agents in familial amyotrophic lateral sclerosis model mice. Exp. Neurol. 179, 176-180.

Nixon, R. A. and Lewis, S. E. (1986) Differential turnover of phosphate groups on neurofilament subunits in mammalian neurons in vivo. J. Biol. Chem. 261, 16298-16301.

Nixon, R. A. and Shea, T. B. (1992) Dynamics of neuronal intermediate filaments: a developmental perspective. Cell Motil Cytoskeleton 22, 81-91.

O'Connell, M. J. and Peters, T. J. (1987) Ferritin and haemosiderin in free radical generation, lipid peroxidation and protein damage. Chem. Phys. Lipids 45, 241-249.

Ozdener, F., Kunapuli, S. P. and Daniel, J. L. (2002) Expression of enzymatically-active phospholipase $\mathrm{C} \gamma 2$ in E. coli. J. Biochem. Mol. Biol. 35, 508-512.

Pall, H. S., Williams, A. C., Blake, D. R., Lunec, J., Gutteridge, J. M., Hall, M. and Taylor, A. (1987) Raised cerebrospinal-fluid copper concentration in Parkinson's disease. Lancet 2, 238-241.

Smith, P. K., Krohn, R. I., Hermanson, G. T., Mallia, A. K., Gartner, F. H., Provenzano, M. D., Fujimoto, E. K., Goeke, N. M., Olson, B. J. and Klenk, D. C. (1985) Measurement of protein using bicinchoninic acid. Anal. Biochem. 150, 76-85.

Stadtman, E. R. (1993) Oxidation of free amino acids and amino acid residues in proteins by radiolysis and by metal-catalyzed reactions. Annu. Rev. Biochem. 62, 797-821.

Treerattrakool, S., Eurwlaichitr, L., Udomkit, A. and Panyim, S. (2002) Secretion of pem-CMG, a peptide in the CHH/MIH/ GIH family of Penaeus monodon, in Phichia pastoris is detected by secretion signal of the $\alpha$-mating factor from Saccharomyces cerevisiae. J. Biochem. Mol. Biol. 35, 476-481.

Yim, M. B., Kang, J. H., Yim, H. S., Kwak, H. S., Chock, P. B. and Stadtman, E. R. (1996) A gain-of-function of an amyotrophic lateral sclerosis-associated $\mathrm{Cu}, \mathrm{Zn}$-superoxide dismutase mutant: an enhancement of free radical formation due to a decrease in $\mathrm{Km}$ for hydrogen peroxide. Proc. Natl. Acad. Sci. USA 93, 5709-5714.

Youdim, M. B., Ben-Schachar, D. and Riederer, P. (1989) Is Parkinson's disease a progressive siderosis of substantia nigra resulting in iron and melanin induced neurodegeneration? Acta Neurol. Scand. 126, 47-54.

Zhu, B. Z., Antholine, W. E. and Frei, B. (2002) Thiourea protects against copper-induced oxidative damage by formation of a redox-inactive thiourea-copper complex. Free Radic. Biol. Med. 32, 1333-1338. 